Kathmandu School of Law Review (KSLR),

Volume 8, Issue 1, 2020, pp 21-39

https:// doi.org/10.46985/kslr.v8i1.2126

(C) KSLR, 2020

\title{
Emergence of Socialism Oriented International Economic Order
}

Iris Lobo*

\begin{abstract}
Winston Churchill had once said that 'Socialism is a philosopby of failure, the creed of ignorance, and the gospel of envy; its inherent virtue is the equal sharing of misery.' This was the belief that was once upheld staunchly in all its rigidity amongst the majority of the people in the neoliberal world; who believed in their own gospel of free markets and worshipped the deity of deregulation. However, when Covid-19 struck society with ruthlessness, the common people and even the high priests of global capitalism were willing to scrap decades of neoliberal orthodoxy to alleviate the catastrophic effects of the pandemic and the subsequent economic crisis. A conversion was vehemently demanded and socialism was to be their baptism. This paper analyses the journey of socialism from a Pre-Covid-19 society, a Covid-19 riddled society and then its emergence into an internationally observed economic order in a Post-Covid-19 world. For contrary to what Churchill believed, the Covid-19 catalyst, as captured in this paper, resulted in the revelation of the shroud of neoliberalism and the failure of the philosophy of laissez. faire, the awakening of 'class consciousness' from its slumber of ignorance, and a gospel of collectivism and communal spirit that the working-class were going to take with, moving forward into a socialism oriented Post-Covid-19 society.
\end{abstract}

\section{Introduction}

In the summer of 1989, Francis Fukuyama, in his essay 'The End of History?' stated

What we may be witnessing is not just the end of the Cold War, or the passing of a particular period of postwar history, but the end of history as such: that is, the end point of mankind's ideological evolution and the universalization of Western liberal democracy and its final form of human government. ${ }^{1}$

Evoking Hegel, Marx, and Kojève; he backs up this claim by arguing that with the

* Iris Anne Lobo is an Indian student planning to pursue her master's degree in Political Science. She holds two bachelor degrees in English Literature and Western Classical Piano respectively. She can be reached at irisannelobo@gmail.com.

This paper was awarded the 2nd Best Paper in the International Research Paper Writing Competition, which was organized by Kathmandu School of Law Review, Amnesty International Fusion Youth Network, and the Cognition Club.

$1 \quad$ Francis Fukuyama, 'The End of History?', The National Interest, 1989, p. 3. 
decadence of fascism and socialism, liberal democracy and the free market economy no longer have any competitors ${ }^{2}$. A befitting counterargument to this claim would ironically be a quote of Milton Friedman, one of the most notable advocates of the free market economy, who said 'reality ensures that the end of history will never come'. ${ }^{3}$ And the reality is such: that although Western liberal democracy saw its victory at the end of the Cold War, the countering ideology of socialism never truly saw its end. The last three decades have seen a slow surge of socialism with Covid-19 acting as a catalyst to the emergence of an internationally observed socialism oriented economic order.

\section{Pre Covid-19: a slow surge of Socialism}

In 1998 Hugo Chávez's landmark victory in the Venezuelan election marked the revolutionary wave and the 'turn towards the left-wing' (giro a la izquierda) governments in Latin American democracies; known famously as 'the pink tide' (marea rosa). Having faced coups and right-wing military dictatorships sponsored by the American Government during the Cold War, ${ }^{4}$ unsuccessful neoliberal policy attempts of privatization, as well as cuts in social spending and foreign investments during the 1990s; these pink tide nations all across Latin America, saw a solidification of a post neoliberalism and an anti-imperialism stance. ${ }^{5}$ These leftist governments maintained their popularity by using the 2000s commodities boom to initiate popular socialist policies. ${ }^{6}$ The results that were yielded from these first pink tide governments included a reduction in income inequality, unemployment, extreme poverty, ${ }^{7}$ food scarcity, and an increase in literacy rates $^{8}$. The presidents Evo Morales of Bolivia, Luiz Inácio Lula da Silva of Brazil and Rafael Correa of Ecuador received international praise for their social reforms while El Salvador, Nicaragua and Costa Rica witnessed notable economic growth.

This leftist hegemony, however, began to crumble by the third decade, mid-2010s, as Latin America saw a right-wing conservative wave known as the 'blue tide' (ola conservadora); a direct reaction to the pink tide. The commodities boom that once yielded a strong economic growth proved to be unstable because of the negative impact of expansionary policy on inflation, non-commodity exports and fiscal deficits. The plummet of international oil prices and a string of corruption scandals of multiple state-officials

\footnotetext{
Francis Fukuyama (n 1).

3 Nathan Gardels, Naomi Klein, Read Milton Friedman's Last Interview', HuffPost, 2007, available at https://m. huffpost.com/us/entry/us_66591?test_ad=taboola_iframe_mw_news, accessed on 24 July 2020.

4 Marcia Esparaza, Henry Huttenbach \& Daniel Feierstein, State Violence and Genocide in Latin America: The Cold War Years, Routledge, 1stedition, 2009, p. 107.

5 Gabriel Pimenta, 'Rethinking Integration in Latin America: The "Pink Tide" and the Post-Neoliberal Regionalism', FLASCO, 2014, p. 2.

${ }^{6}$ Daniel Rodriguez, 'Life after Populism?: Reforms in the Wake of the Receding Pink Tide', Georgetown Journal of International Affairs, 2016, p. 56.

7 Gabriel Pimenta (n 5).

8 Jared Abbot, 'Will the Pink Tide Lift All Boats? Latin American Socialisms and Their Discontent', Democratic Socialists of America, 2014, available at https://www.dsausa.org/democratic-left/will_the_pink_ tide_lift_all_boats/, accessed on 24 July 2020.
} 
added insult to injury which resulted in several pink tide nations turning towards the ideologies of Western liberal democracy that they once vehemently rejected. ${ }^{9}$

However, what was once seen as the recess of the pink tide, gained new hope in the final parts of the third decade, with leftist presidential candidate Andreás Manuel López. Obrador's victory in 2018, reigniting the resurgence of the pink tide movement by adding Mexico to the list of countries, while in 2019, Alberto Fernández's win marked the return of Argentina to the pink tide nations. The release of imprisoned former president Lula of Brazil sparked enthusiasm as it was indicative that the champion of Brazil's left was back. Bolivia, despite having averted a coup in 2019 and having faced challenges from the country's oligarchy, elected Evo Morales again as president. Accused of election fraud by the Organization of American States, Morales was forced to step down. A study published by the researchers at the MIT Election Data and Science Lab concluded that the allegation was fraudulent ${ }^{10}$ but the damage was done and Morales, after having his life threatened, sought asylum in Mexico ${ }^{11}$. The memory of the violence that was born from this coup will likely mobilize more people during the next election, to re-elect Morales' Movement for Socialism. In 2019, America attempted an open coup against Nicolás Maduro's Venezuelan government ${ }^{12}$. They set up a predator government to weaken Maduro; the coup striking hard as Venezuela found its gold reserves in the UK stolen and its facilities to sell oil sealed. ${ }^{13}$ Despite the economy remaining fragile, the Government did not fall and political commitment towards socialism was strengthened. In 2019, Ecuador and Chile witnessed riots in favor of leftist policies. President Lenin Moreno, after winning the elections, distanced himself from predecessor Rafael Correa and shifted his policies towards the center which eventually saw Ecuadorians rioting because of his austerity measures and fuel subsidies $;{ }^{14}$ while in Chile, President Sebastián Piñera saw riots, demanding his resignation over the hike in subway fares, increased cost of living, privatization, and inequality caused by neoliberal policies. ${ }^{15}$

9 Daniel Rodriguez (n 6).

10 Dan Collyns, 'No evidence of fraud in Morales poll victory, say US researchers', The Guardian, 1 March 2020, available athttps://www.theguardian.com/world/2020/mar/01/no-evidence-of-in-morales-pollvictory-say-us-researchers-bolivia, accessed on 24 July 2020.

11 Debbie Sharnak, 'Why Mexico is a haven for political exiles like Bolivia's former president Evo Morales', The Washington Post, 8 December 2019, available at https://www.washingtonpost.com/outlook/2019/12/08/ why-mexico-is-haven-political-exiles-like-bolivias-former-president-evo-morales/, accessed on 24 July 2020 .

12 Mehdi Hasan, 'The "coup” Attempt in Venezuela Seems Ridiculous. But Don't Forget- Regime Change is the U.S. Goal', The Intercept, 9 May 2020, available at https://theintercept.com/2020/05/09/venezuelacoup-regime-change/, accessed on 24 July 2020.

13 BBC News, 'Venezuela gold: UK High Court rules against Nicholás Maduro', The British Broadcasting Corporation, 2 July 2020, available athttps://www.bbc.com/news/world-latin-america-53262767, accessed on 24 July 2020.

14 José Cabrera, 'Hundreds Arrested in Ecuador Unrest', The New York Times, 4 October 2019, available athttps://www.nytimes.com/2019/10/04/world/americas/hundreds-arrested-in-ecuador-unrest.html, accessed on 24 July 2020.

15 TheIndianExpress, 'Chile rocked by months of riots over inequalities', The Indian Express, 2 January 2020, available at https://www.google.com/amp/s/indianexpress.com/photos/world-news/chile-rocked-bymonths-of-riots-over-inequalities-6195901/lite/, accessed on 24 July 2020. 
While several Latin American countries saw a slow surge in socialism following the conservative wave, the neoliberal western world that was believed to be the endpoint of mankind's ideological evolution, witnessed socialism gaining momentum and its emergence as a competitor that was once believed to be defeated. Bernie Sanders, the first openly socialist candidate to run for presidency in America, was backed by a grassroots movement of working-class and young supporters. Funded by the people, his goals included raising taxes on capital gains and the wealthiest $1 \%$, lowering taxes on middle and lower classes, support for legislation that would make it easier for workers to join a labor union, a federal jobs guarantee, doubling of the minimum wage, an ownership stake in companies they work for, Medicare for all and free college tuition ${ }^{16}$. Although he didn't win the Democratic nominee in 2020, his movement continued to grow exponentially and when Covd19 knocked on American doors his theoretical goals turned into nationwide demands to be put into practice.

Other neoliberal western democracies also witnessed a slow surge of socialism with left-wing party Sinn Fein of the Republic of Ireland and Northern Ireland gaining $24.5 \%$ votes, disrupting the two-party system ${ }^{17}$. In 2018, Québec Solidaire was granted official party status in Canada and later recognized as the second opposition party behind the Liberals ${ }^{18}$.

In India, a non-western country that moved towards neoliberalism in the 1990s saw the Aam Aadmi Party; ${ }^{19}$ a center-left party seize control in the nation's capital since 2013 while the Left Democratic Front, a coalition of several left-wing parties came to power in the State of Kerala by defeating the centrist government that had its foothold over the State since the 1980s. ${ }^{20}$

\section{The Covid-19 Catalyst}

The Corona virus outbreak that was first identified in December in Wuhan and declared to be a pandemic by the WHO on 11 March 2020, is often viewed as the source of the emergence of an internationally observed socialism oriented economic order. However,

16 BBC News, 'Bernie Sanders: 18 things the democratic front-runner believes', The British Broadcasting Corporation, 28 February 2020, available athttps://www.bbc.com/news/magazine-35364868, accessed on 24 July 2020.

17 Rory Carroll, 'Sinn Féin declares victory in Irish general election', The Guardian, 11 February 2020, available athttps://www.theguardian.com/world/2020/feb/10/sinn-fein-declares-victory-irish-general-election, accessed on 24 July 2020.

18 Julia Page, 'Québec Solidaire triples number of seats, gets off island of Montreal', Canadian Broadcasting Corporation, 28 October 2018, available at https://www.google.com/amp/s/www.cbc.ca/amp/1.4846154, accessed on 24 July 2020.

19 Prabash Dutta, 'Delhi election results: AAP wins all 12 seats reserved for SC candidates', IndiaToday, 11 February 2020, available athttps://www.indiatoday.in/elections/delhi-assembly-polls-2020/story/resultsaap-arvind-kejriwal-dalits-sc-seats-bjp-ravidas-temple-1645449-2020-02-11, accessed on 24 July 2020.

20 Sneha Koshy, 'By-Election Result 2019: Left Wins Kerala Assembly Seat After Decades Of CongressLed UDF Rule', New Delhi Television, 27 September 2019, available at https:/ /www.ndtv.com/kerala-news/ by-election-result-2019-left-wins-kerala-assembly-seat-after-decades-of-congress-led-udf-rule-2108140, accessed on 24 July 2020. 
as Kwame Nkrumah said 'Socialism is not spontaneous. It does not arise of itself'21, just as socialism didn't materialize out of thin air because of a pandemic. It was rather a by-product of the slow surge of socialism that was gearing up since the 1990s as well as Covid-19 acting as the catalyst to the emergence.

\section{A. Welfare State and Socialism's Fate}

A study on the spending trajectories of 18 Western countries illustrated that World War 2 created new welfare constituencies and also changed politics that facilitated the expansion of the welfare states in the post war period. The study also asserted that the cruelties of war generated social needs of a magnitude that required government action $^{22}$. WW2 is a pertinent historical parallel to Covid-19 as the cruelties of the pandemic have similarly resulted in munificence displayed by governments.

Malta, a neoliberal country has the biggest Covid-19 stimulus package which includes a refund of $50 \%$ for electricity bills, a one-time grant of up to EUR 2,500 to cover rent for businesses and tax refunds to workers earning less than EUR 60,000. Even people who had to postpone their weddings due to Covid-19 are to receive a reimbursement of their forfeited deposit of a maximum of EUR 2,000. The Government has also lent its support to the real estate industries, dropped prices of petrol and diesel as well as allocated funds to assist NGOs. ${ }^{23}$

Japan unveiled their stimulus package, the second largest in the world, equivalent to $20 \%$ of their annual economic output; which included a stimulus check of $\$ 930$ for every citizen as well as non-residents. Other neoliberal governments also gave their citizens stimulus checks. America gave its citizens $\$ 1,200$, Canada gave $\$ 2,000$ per month to the unemployed, Hong Kong gave $\$ 1,284$, Ireland is giving $\$ 220$ a week, Australia gave $\$ 750$ in cash to low income earners, Italy gave self-employed and seasonal workers \$ 650 while Germany gave $\$ 350$ for each child and $\$ 5,422$ to freelancers. In neoliberal countries like the Netherlands, the Government agreed to pay $90 \%$ of workers' salaries, in Denmark $75 \%$ to $90 \%$, in the UK $80 \%$, in Hong Kong 50\%, and in South Korea $70 \%$. Far-right party Shiv Sena, in Maharashtra, a state in India urged landlords to stop collecting rent for 3 months while other neoliberal countries like Slovenia, Singapore, Germany, Australia and UK passed rent relief legislation.

While these multi-trillion-dollar packages are both corporate and individual socialisttype plans of unprecedented magnitude, the immense scale of state intervention isn't an assault on capitalism and a turn towards socialism but more so an alternative method of managing capitalism; the alternative being Welfare States. O'Connor in his study of

\footnotetext{
$21 \quad$ Kwame Nkrumah, Two Myths, Panaf Books, revised edition, 1966, p. 12.

22 Herbert Obinger \& Carina Schmitt, 'The impact of the Second World War on postwar social spending', European Journal of Political Research, volume 57:2, 2017, p. 496.

23 Rosanne Bonnici, 'Malta Economic Stimulus Package Launched', Lexology, 10 June 2020, available at https://www.lexology.com/library/detail.aspx?g=e853d323-8797-4fdb-8c04-28d0f51f8687, accessed on 25 July 2020.
} 
the 'Fiscal Crisis of the State' argued that 'the capitalistic state must try to fulfill two basic and often mutually contradictory functions - accumulation and legitimization' which is indicative that a Welfare State in an advanced capitalistic society serves the purpose of stabilizing, continuing and ensuring the functioning of the economic system, integration of social classes as well as maintaining social order. Because of the 'dual and contradictory character of the capitalist society,' the Welfare State's spending involves both the functions of accumulation and legitimization simultaneously. He argues that the purpose of some transfer payments, such as income payments to the poor, is to 'pacify and control the surplus population' ${ }^{24}$ therefore, making his argument a contention that these stimulus packages introduced by neoliberal governments under the pretext of helping the ordinary citizens are nothing more than a way to use taxes paid by the working class to absorb the losses incurred by businesses and to appease the masses in order to prevent the disruption of the neoliberal hegemonic system. So when Ludwig von Mises who is known for his economic arguments against socialism, stated that 'the Welfare State is merely a method for transforming the market economy step by step into socialism,; ${ }^{\prime 25}$ he couldn't be more wrong as the welfare state exists to protect the status quo of capitalism. It is by no means a method of transformation; however, what was a real catalyst of transformation is Covid-19, for the pandemic shattered through this magnanimity displayed by governments and reflected to the masses the reality of neoliberalism.

\section{B. Unmasking Neoliberalism}

The WHO Director-General, in his opening remarks at the media briefing on Covid-19, said 'this virus is presenting us with an unprecedented threat. But it's also an unprecedented opportunity to come together as one against a common enemy an enemy against humanity ${ }^{26}$. Although well intentioned, this ad nauseam narrative of 'we are all in this together', papers over the Pre Covid-19 social inequalities and class struggles exacerbated by neoliberalism.

When the Taylor-Fordist pattern of accumulation and the Keynesian regulations in the postwar Welfare States collapsed after the 1970s, especially during the Thatcher and Reagan administrations, it resulted in social rights getting razed, an aversion towards proposals that weren't contrary to the interest of capital and the spread of an exacerbated subjectivism and individualism. This was a product of the bourgeois class usurping new mechanisms of social control under the neoliberal umbrella which only grew and expanded with the fall of the USSR, the absence of a 'socialist threat' and the presumption of the 'end of socialism'. Now, the argument often heard is that had the

\footnotetext{
24 James O'Connor, The Fiscal Crisis of the State, Routledge, revised edition, 2017, p. 35.

25 Ludwig Von Mises, 'There Is Freedom or There Is Not: Mises Critiques Hayek', Foundation for Economic Education, 21 December 2016, available at https://www.google.com/amp/s/fee.org/articles/there-isfreedom-or-there-is-not-mises-critiques-hayek/amp, accessed on 25 July 2020.

26 WHO, 'WHO Director - General's opening remarks at the media briefing on COVID-19', World Health Organisation, 2020, available at https://www.who.int/dg/speeches/detail/who-director-general-s-openingremarks-at-the-media-briefing-on-covid-19---18-march-2020, accessed on 26 July 2020.
} 
pandemic not existed, the neoliberal system that held its dominance for so long, would not be crumbling. But the reality, however, is that economic crises are part and parcel of capitalism and are inevitable. History kept repeating itself through economic crises like the short-lived mining boom in Australia (1978-83), Black Monday (1987), Asian financial crisis (1997), the dot-com bubble and bust (1999-2001), the Global Financial crisis (2008); these being the most notable and disastrous. Richard D. Wolff, when talking about the instability of capitalism stated

Every 47 years, in every capitalistic country, on average, there's an economic downturn. Not due to nature and not due to war, just built into the system. It's called a 'business-cycle' because it always comes back. Millions of people lose work, businesses go out of business; a crazy crash. You know what it's like if you pick up the Financial Press. You know we're waiting for the next one to hit this year or next. Mr. Trump's biggest worry about being re-elected is that it'll happen too soon. ${ }^{27}$

Just four months later, his words came true, with Covid-19 producing the exact same outcome. Usually, when faced with a crisis, governments intervene and act to mitigate the impact, sometimes successfully, other times unsuccessfully. But when the economy recovers, the dominant narrative circulated is that it was a 'once-off shock' and the recovery was a return to normality. What made the Covid-19 impact different is that people did not want to return to 'normal' and with the veil being lifted; a myriad of citizens began to ring the death-knell of neoliberalism. Covid-19 was a stinging indictment of the structural weaknesses of neoliberalism, for it wasn't merely about the chance arrival of a novel pathogen but more about the virus in conjunction with the social, economic and political circumstances under which it spread.

Within the first few weeks of the outbreak, millions of people were rendered unemployed. Unlike their wealthy counter-part neoliberal nations, the poorer nations didn't offer their unemployed citizens any relief, leaving them to fend for themselves. Howard Zinn once said that 'capitalism has always been a failure for the lower classes. It is now beginning to fail for the middle classes ${ }^{228}$; his claim, truer now more than ever as 8 million of the 170 million middle-class people in Africa could be thrust into poverty adding to the 58 million people already threatened by $\mathrm{it}^{29}$ while 139 million Indians will likely run out of savings by the end of July, $30 \%$ being the middle class ${ }^{30}$. Richard D. Wolff also stated that

27 ReasonTV, 'Capitalism vs. Socialism: A Soho Forum Debate', YouTube, 2019, 00:10:37-00:11:11, available at https:/ / youtu.be/YJQSuUZdcV4, accessed on 26 July 2020.

28 Howard Zinn, A People's History of the United States, Harper Collins, revised edition, 2010.

29 Abdi Dahir, 'Africa's growing middle class being battered by coronavirus; COVID-19 could push $58 \mathrm{mn}$ into extreme poverty', Firstpost, 30 June 2020, available athttps://www.firstpost.com/health/africas-growingmiddle-class-being-battered-by-coronavirus-covid-19-could-push-58-mn-into-extreme-poverty-8540161. $\mathrm{html} / \mathrm{amp}$, accessed on 26 July 2020.

30 Ganesh Rao, '139 million people across Indian cities likely to run out of savings by month-end', Mint, 16 June 2020, available athttps://www.livemint.com/news/india/139-million-people-across-indian-citieslikely-to-run-out-of-savings-by-month-end-11592205172025.html, accessed on 26 July 2020. 
In capitalism, "haves" rip off "have nots". When a revolution threatens, "haves" fund a temporary middle class, the "think they haves". Once the revolution threats pass, funding stops for the "think they haves". They sink back into "have nots". To grasp this pattern is to bring capitalism's end nearer. ${ }^{31}$

The Covid-19 crisis, by itself, reduced the "think they haves" into "have nots", lifting the guise of middle-class wealth. It is this class consciousness of the middle-class, the realization of how close they are to being "have nots" than they are to ever being "haves", and the threat of the consequences of capitalism that contributed to the shift towards the demand for a socialism oriented international economic order, with the two classes becoming allies in class warfare.

Unemployment often exacerbates food insecurity and as per the United Nations World Food Program, an estimated 265 million could face food insecurity by the end of 2020, up from the 135 million people before the Covid-19 crisis. With regards to food shortages, the UNWFP stated that the hotspots included the poor, the vulnerable and more than 820 million people who were already chronically food insecure before the Covid-19 crisis impacted movement and incomes. ${ }^{32}$

Housing and living conditions are also exacerbated by unemployment as 28 million Americans face eviction in July. While there is a possibility of America passing a 'Rent Relief Act' which would ban eviction and foreclosures for a year for tenants and homeowners; the Trump government has not shown any inclination that they would $^{33}$. On the other hand, neoliberal countries like India, South Africa, Pakistan, Iran, Iraq, Philippines, Brazil, Ethiopia, Kenya, South Sudan are witnessing large scale evictions and demolitions because the governments aren't providing relief to their most vulnerable citizens.

The migrant workers crisis, however, is what really shook the fabric of neoliberalism, especially in India. Indrudaya Rajan, faculty at the Centre for Development Studies in India stated that 'this is a refugee crisis now and not merely a migrant crisis' also adding, 'we are finally acknowledging that migrants exist in huge numbers' ${ }^{34}$ indicative that the urban Indians were ignorant of the hidden majority (estimated 500 million) of migrants living in the cities until Covid-19. Originally from villages, these migrants are daily wage laborers who work in the informal sector and are often denied adequate remuneration, food, healthcare, housing and sanitation. The government announced a nation-wide

31 Richard Wolff, Twitter, 2019, available at https://mobile.twitter.com/profwolff/ status/1122541735471484928, accessed on 26 July 2020.

32 The World Bank, 'Food Security and COVID-19', available at https://www.worldbank.org/en/topic/ agriculture/brief/food-security-and-covid-19, accessed on 26 July 2020.

33 Jose Sepulveda, 'Landlords are encouraged to think creatively as 28 million Americans face eviction', Consumer News and Business Channel, 2020, available at https://www.cnbc.com/amp/2020/07/24/28million-americans-face-eviction-because-they-cannot-afford-rent.html, accessed on 26 July 2020.

34 Harish Pullanoor, 'The internal and external migrants, together, pose a refugee crisis that India is illprepared for', Quartz India, 19 May 2020, available at https://qz.com/india/1858209/covid-19-lockdownexposes-indias-looming-migrant-refugee-crisis/, accessed on 26 July 2020. 
lockdown with a mere 4-hour notice; resulting in the largest migration crisis since India's Partition with Pakistan. Unable to survive in the cities with businesses coming to a standstill, they began to walk back to their villages as there were no provisions of transport due to the lockdown on vehicular movement as well. Stranded Workers Action Network found that $50 \%$ of workers had rations left for less than one day. More than 300 migrant workers died because of the lockdown due to reasons that included exhaustion, starvation, police brutality, road and railroad accidents, suicides, and being denied timely medical care. ${ }^{35}$ It is very unlikely that the migrant workers will return to the cities after having dealt with the arduous struggle of being stranded but if they do return, the suspension of Labor Laws by various State governments greedily awaits them, to exploit the exploited, to rebuild a system that was never designed for their benefit. As the first Prime Minister of India, Pandit Jawaharlal Nehru, once said, 'man should not be sacrificed for money', ${ }^{36}$ and if his successors were to heed the words of the man who fought for the freedom of India, this neoliberal cesspool of labor crises would not be an issue. Covid-19 has also created a serious problem for the estimated 5 million Central Asian migrants, predominantly from Uzbekistan, Tajikistan and Kyrgyzstan, who live and work in Russia. Many of these migrants have lost their jobs and with the border remaining closed they are unable to return home. Despite the Russian government paying them unemployment benefits, they are major sources of remittance in their nations, which makes up a staggering $30 \%$ of the GDP. ${ }^{37}$

Unemployment, food insecurity, rent and migrant workers have always been threats to class power despite Covid-19 posing as a new crisis. A distinctive feature of the Marxist theory of crisis is on the 'necessity' of a crisis; it being an essential and ineradicable feature of a capitalist society, that defines the objective limits of capitalism and also the necessity of socialism. With Covid-19 exacerbating the objective limits of capitalism; it has become glaringly obvious to the working-class that bringing about justice and rising up against the exploitative bourgeois class is a requirement. Karl Marx said

[T] he civilization and justice of bourgeois order comes out in its lurid light whenever the slaves and drudges of that order rise against their masters. Then this civilization and justice stand forth as undisguised savagery and lawless revenge. Each new crisis in the class struggle between the appropriators and the producers brings out this fact more glaringly. ${ }^{38}$

While undisguised savagery or lawless revenge, haven't to the extent as Marx claims been

35 Champa Patel, 'COVID-19: The Hidden Majority in India's Migration Crisis', Chatham House, 2020, available at https://www.chathamhouse.org/expert/comment/covid-19-hidden-majority-indias-migration-crisis, accessed on 26 July 2020.

36 Jag Mohan, 'Jawaharlal Nehru and his Socialism', India International Centre Quarterly, volume 2:3, 1975, p. 183.

37 OECD, 'COVID-19 crisis response in Central Asia', Organisation for Economic Co-operation and Development, 2020, available at https://www.oecd.org/coronavirus/policy-responses/covid-19-crisis-response-incentral-asia-5305f172/, accessed on 26 July 2020.

38 Karl Marx, 'The Fall of Paris', Marxists Internet Arcbive, available at https://www.marxists.org/archive/ marx/works/1871/civil-war-france/, accessed on 27 July 2020. 
seen yet, the class struggles have become glaringly obvious. One of these class struggles is the privilege of being able to 'social distance'. Marx argues that 'the propertied class and the class of the proletariat present the same human self-estrangement. But the former class feels at ease and strengthened in this self-estrangement, it recognizes estrangement as its own power and has in it the semblance of a human existence ${ }^{39}$. Although this is an argument about alienation with respect to work, the premise of self-isolation is a valid comparison with regards to Covid-19 as the rich are at ease and strengthened when they social distance while the proletariats face difficulty and are weakened, for they don't have the luxury to do so. The productivity of the proletariats is remunerated with the wages they receive for their labor, and when the pandemic worsened, the difficulty and weakness they faced was a result of being put in a compromising situation of having to forfeit social distancing and their health or lose out on the wages that keep them alive; with the pursuit of either ultimatum resulting in death. Marx did say 'capital is dead labor, which, vampire-like, lives only by sucking living labor, and lives the more, the more labor it sucks ${ }^{40}$. If the working class had rights and ownership over their labor, as promised in a socialist system; they would not be put in this predicament. When demands began, to reopen the economy despite growing cases, it was this proletariat class that was made to be the sacrificial lambs, forced to risk their lives for the sake of the economy and the corporations that profit from them. As Noam Chomsky puts it, 'a basic principle of modern state capitalism is that costs and risks are socialized to the extent possible, while profit is privatized ${ }^{41}$. The bourgeois class, including an economic advisor of Mr. Trump, went as far as to refer to the working class that were being put in harm's way as "Human Capital Stock" ${ }^{\prime 2}$, subsuming human life to a narrow economic calculus. Leon Trotsky, long before spoke about this saying, 'as long as human labor power, and, consequently, life itself, remain articles of sale and purchase, of exploitation and robbery, the principle of "sacredness of human life" remains a shameful lie, uttered with the object of keeping the oppressed slaves in their chains ${ }^{243}$.

A class struggle that was also brought to the forefront was farmers dumping thousands of gallons of fresh milk and other farm produce despite the alarming rates of food insecurity. In America, the farmers claimed that the lockdown resulted in a breakdown in their supply chain of usual buyers like restaurants and schools, rendering them unable to 'sell' their products; ${ }^{44}$ while in India where the farmers are as poor as the proletariats,

\footnotetext{
39 Gerald Cohen, 'Bourgeois and Proletarians', Journal of the History of Ideas, volume 29:2, 1968, p. 211.

40 Edwin West, 'Marx's Hypotheses on the Length of the Working Day', Journal of Political Economy, volume 91:1, 1983, p. 1227.

41 Noam Chomsky, Twitter, 2017, available at https://mobile.twitter.com/noamchomskyT/ status/896771696551759874, accessed on 26 July 2020.

42 Rachel Ranosa, 'Economist under fire for calling workers 'human capital stock', Human Resources Director, 28 May 2020, available at https://www.hcamag.com/au/news/general/economist-under-fire-for-callingworkers-human-capital-stock/223605, accessed on 26 July 2020.

43 Leon Trotsky, 'Terrorism and Communism', Marxists Internet Archive, available at bttps:/ / wmm.marxists.org/ archive/trotsky/1920/terromm/ch04.htm, accessed on 26 July 2020.

44 Susie Cagel, 'A disastrous situation: mountains of food wasted as coronavirus scrambles supply chain', The Guardian, 9 April 2020, available at https://www.theguardian.com/world/2020/apr/09/us-coronavirus-
} 
farmers poured milk and threw fruits on the road in protest, demanding remuneration from the government ${ }^{45}$. Here, both the rich and the poor farmers suffered losses, but it doesn't change the fact that food commodities in a neoliberal society are produced for the intent of monetary gain rather than for the consumption of the hungry. As Charles Fourier said, 'it is society as a whole which suffers by such waste, which you can see taking place every day under the cover of the philosophical principle: 'Laissez faire les marchands. ${ }^{\prime 6}$

\section{Public Health and Public Wealth}

Public health was brought to the forefront of the discussion, during the Covid-19 outbreak. In the initial stages, mortality rate and surging cases were the focal points of scrutiny, but further on, the healthcare system as a whole became central to every citizen's concern. From the beginning itself, Covid-19 looked like it would be an impending crisis to the healthcare system. Although it seemed like the crisis was an exogenous shock, it was rather a series of poor neoliberal policy failures. The growing and expanding privatization of healthcare in neoliberal countries has contributed to the development of the innate neoliberal essence of consumerism, competition and less government regulation. Rick Scott said, 'I believe that free market principles will solve our healthcare problems'; one can argue against the fallacy that is this statement, however, it does not change the fact that privatization itself treats healthcare as a commodity thereby making illnesses profitable; and 'when morality comes up against profit, it is seldom that profit loses', ${ }^{47}$ as Shirley Chisholm says. What it also does is make treatment dependent on the person's ability to pay; of course, this payment may be partially mediated by insurance, but the mere construction of a system with private hospitals and private insurances is a capitalistic decree. Tommy Douglas, the Father of Medicare, who introduced the universal health insurance system once said, 'I came to believe that health services ought not to have a price tag on them, and that people should be able to get whatever health services they require irrespective of their individual capacity'. ${ }^{48}$

A socialist system would offer exactly that since profits are not a driving force; it goes beyond the response to the demands of the market and private interests, and builds a structure that can respond to an emergency; including an emergency like Covid-19.

outbreak-agriculture-food-supply-waste, accessed on 26 July 2020.

45 Jayshree Bhosale, 'Farmers in Maharashtra hold protest as milk prices fall $40 \%$ after Covid outbreak', The Economic Times, 20 July 2020, available athttps://www.google.com/amp/s/m.economictimes.com/news/ economy/agriculture/farmers-in-maharashtra-hold-protest-as-milk-prices-fall-40-after-covid-outbreak/ amp_articleshow/77072215.cms, accessed on 26 July 2020.

46 Charles Fourier, 'On Economic Liberalism', Marxists Internet Arcbive, available at https://www.marxists. org/reference/archive/fourier/works/ch11.htm, accessed on 26 July 2020.

47 Scott Williams, 'The Circle Association's African American History of western new York state', University at Buffalo, available at www.math.buffalo.edu/ sww/0history/chisholm.html, accessed on 27 July 2020.

48 Thomas Ponniah, 'The Tommy Douglas Institute: Igniting a commitment to social justice', Rabble, 2014, available at https://rabble.ca/columnists/2014/03/tommy-douglas-institute-igniting-commitment-tosocial-justice, accessed on 27 July 2020. 
Not only that, if a socialist approach was applied to insurance and healthcare, it would become easier to allocate skills and supplies based on need. When paralyzed with the pandemic, a clash arose between capitalist principles and human needs, between the neoliberal healthcare system and the socialist system; but since there is not a mode through which human needs can be measured through a market, even in highly capitalist states there was recognition among the people for the need of socialist principles in the provisions of healthcare.

Their first inkling that the capitalistic system was unjust was when the common people were struck with the brazen display of price gouging. Price gouging especially during a pandemic is not only unethical but also has the most detrimental impact on the poor individuals and families who are already the most vulnerable during crises. ${ }^{49}$ Citizens were abhorred with the sky-rocketing prices of basic medical requirements like masks, hand sanitizers, hand wipes, gloves; causing duress among the already fearful masses. Covid-19 put a spotlight on the practice of unjustifiably and unreasonably increasing the prices of high-demand goods and services; this was clearly observed with the difference between their prevailing Pre-Covid-19 cost and the exorbitant prices in the midst of the pandemic.

While abhorred by their own exploitation, they were just as livid when they became aware of 'scarce and threatened materials' required for frontline health workers in hospitals that included: N95 masks, ventilators, hydroxychloroquine and other medicines, sterilization devices, medical gowns and personal protective equipment. ${ }^{50}$ The outrage over illequipped doctors and nurses dying from the virus further solidified among the people the requirement for justice and a system alternative to the reality they were living in.

They then soon uncovered the sources from where masks and sanitizers were produced: some included prison labor and sweatshops. While the relationship between incarceration rates, prison labor, profit interests and labor markets are often understudied, Covid-19 brought attention to this plight, highlighting that even behind prison bars, exploitation still persists. Prisons exist to rehabilitate convicts; not for the exploitation of free labor. What makes it even worse is that, despite their labor, most of them are denied access to the very products they're making. ${ }^{51}$ Louis Auguste Blanqui had once questioned this injustice; 'is the capital only productive in the workers' hands on condition that it not belong to them?' he had asked. Free labor, overtime working hours, inhospitable working environments, no rights, no freedom; there's a word we use to describe situations like this: Slavery. 'Capitalism is a development by refinement from feudalism just as feudalism is development by refinement from slavery. Capitalism

49 Joe Carter, 'Thinking about the Ethics and Economics of 'Price Gouging', Moral Markets, 30 August 2017, available at https://www.moralmarkets.org/2017/thinking-ethics-economics-price-gouging/, accessed on 27 July 2020.

50 U.S. DOJ, 'Combating Price Gouging \& Hoarding', The United States Department of Justice, available at https://www.justice.gov/coronavirus/combattingpricegouginghoarding, accessed on 28 July 2020.

51 'Prisoners make COVID-19 Masks but can't use them', News and Letters Committees, 13 April 2020, available at https://newsandletters.org/incarcerated-people-producing-covid-19-masks-denied-access-to-them/, accessed on 28 July 2020. 
is but the gentlemen's method of slavery', said Kwame Nkrumah. ${ }^{52}$

Now with regards to sweatshops, Borzou Daragahi reported that 'counterfeit masks are being shipped worldwide, often made in unsterile sweatshops, labeled with names of well-known medical supply companies and stamps ${ }^{53}$. In most third world countries, these sweatshops are built on the labor of the marginalized poor and also the exploitation of child-labor. ${ }^{54}$ It is these jarring revelations that shook the foundation of neoliberal societies, the harsh side of capitalism flooding the minds of the previously unaware people; Covid-19 amplifying the grievances of the exploited to volumes never heard before. With the masses now aware, they knew they wanted a change in the system.

\section{Workers to 'Woke'}

'Woke' is a slang term broadly associated with being aware and actively attentive to important facts and issues especially issues of social justice while slang, is a language peculiar to a particular group; in this case, the working class. Working-class consciousness is something Karl Marx previously discussed; 'class consciousness' as Marx puts it, is in reference to a developing process wherein those who share common objective relations (a 'class-in-itself') become aware of the class interests they share. They then begin to work together to achieve common class aims, acting as a self-conscious social grouping (a 'class-for-itself'). Class position, in the classic Marxist formulation, leads to class consciousness, which in turn leads to class action. By identifying an underlying economic 'base' within society, which determines the political and social superstructure; he argues that economic developments that make the conditions of class inequality increasingly clear and transparent will result in the emergence of a revolutionary class consciousness of the working class. ${ }^{55}$ Covid-19 was the catalyst that made it increasingly clear and transparent to the working class, the inequalities that they were victims of, and soon their class consciousness materialized into class action as wide-spread internationally observed strikes were seen. Even before the pandemic, data from the Bureau of Labor Statistics showed an upsurge in major strike activity in 2018 and 2019, indicative that this class action was already in the works, Covid-19 exacerbating it. ${ }^{56}$

It started with demands for hazard pay by frontline health workers citing heightened risks to justify increased wages. This was followed by essential workers, who collectively

52 Kwame Nkrumah, The Jewel of Africa, African literature, revised edition, 1970, p. 22.

53 Bourzou Daragahi, 'Total disregard for people's lives: Hundreds of fake masks flooding markets as coronavirus depletes worlds supplies', The Independent, 25 March 2020, available at https://www. independent.co.uk/news/health/coronavirus-face-mask-fake-turkey-medical-supply-shortage-covid19-a9423426.html, accessed on 28 July 2020.

54 Alessandra Mezzadri, 'In parts of Asia, coronavirus safety gear is being produced in sweatshop-like conditions', Scroll.in, 5 July 2020, available athttps://amp.scroll.in/article/966101/in-parts-of-asiacoronavirus-safety-gear-is-being-produced-in-sweatshop-like-conditions,, accessed on 28 July 2020.

55 Wendy Bottero, 'Class Consciousness' The Blackwell Encyclopedia of Sociology (2007).

56 Heidi Shierholz, Margaret Poydock, 'Continued surge in strike activity signals worker dissatisfaction with wage growth', Economic Policy Institute, February 11 2020, available at https://www.epi.org/publication/ continued-surge-in-strike-activity/, accessed on 28 July 2020. 
realized how much society depends on them to function, demanding an increment in wages, citing the same reasons as health workers. Amazon witnessed multiple strikes in different countries of the world. Bus drivers, distribution and logistics shift workers, food processing workers, manufacturing workers, restaurant workers, retail workers, sanitation workers and shipping workers from all over the world went on strikes due to factors that included: low wages and requirement of hazard pay, unsafe working environments (exacerbated by poor social distancing) and a lack of personal protective equipment; pressurizing businesses to meet their demands or government-intervention. 'It is impossible to lead strike struggles' as Leon Trotsky says, 'without entering at a certain moment into negotiations with the capitalists or their plenipotentiaries, ${ }^{57}$ And while the majority of these strikes were negotiations, nonetheless, it is a step towards strengthening the power of the working class and their commitment to bringing about systemic change.

This power was further strengthened in the wake of the Black Lives Matter protests in America. What started out as protests against the racist killings by the police of George Floyd and other black people before him, eventually turned into demands for justice, reforms in the system, and even abolishing powerful institutions like the police. Malcolm X said, 'you can't have capitalism without racism ${ }^{58}$ and Albert Parsons said, 'the capitalistic system that we have today would not exist twenty-four hours if it were not held together by the bayonets and the clubs of the militia and police'. ${ }^{59}$ It is no wonder why Americans all over the country have been demanding to defund the police. The demand is to redirect and reallocate their funds into social services, as the activists in favor claim that the funds will go directly into addressing social issues like poverty, homelessness and mental disorders. While police abolitionists called for the replacement of the current police system with another system of public safety and the investment into community-building by using police funds for housing, employment, healthcare and education. ${ }^{60}$ W.E.B. DuBois called this 'abolition democracy' which is the project of building up radical community-powered institutions to supplant oppressive social structures; ${ }^{61}$ here the structure being the extremely overfunded custodians of capitalism, who also disproportionately jail and kill black people. ${ }^{62}$ Protests currently continue to persist, with even peaceful protesters being met with police brutality in the

57 Internet Archive, 'Trotsky Quotes', Marxists Internet Archive, available at https:/ /www.marxists.org/archive/ trotsky/quotes/.htm, accessed on 29 July 2020.

58 Ray Smith, 'Malcolm X: "You show me a capitalist, I'll show you a bloodsucker.", Socialist Appeal, 2015, available at https://www.socialist.net/malcolm-x-you-show-me-a-capitalist-i-ll-show-you-a-bloodsucker. htm, accessed on 29 July 2020.

59 Shawn Wilbur, 'Albert R. Parsons on Anarchy (1887)', The Libertarian Labyrinth, 2016, available at https:/ / www.libertarian-labyrinth.org/anarchist-beginning/albert-r-parsons-on-anarchy-1887/, accessed on 29 July 2020.

60 Sean Illing, 'The "abolish the police" movement explained by 7 scholars and activists', Vox, 12 June 2020 , available athttps://www.vox.com/policy-and-politics/2020/6/12/21283813/george-floyd-blm-abolishthe-police-8cantwait-minneapolis, accessed on 30 July 2020.

61 Allegra McLeod, 'Envisioning Abolition Democracy', Harvard Law Review, volume 132:6, 2019, p. 1613.

62 Niall McCarthy, 'Police Shootings: Black Americans Disproportionately Affected', Forbes, 2020, available at, https://www.forbes.com/sites/niallmccarthy/2020/05/28/police-shootings-black-americansdisproportionately-affected-infographic/amp/, accessed on 30 July 2020. 
form of excessive force, tear gas, rubber bullets, pepper-spraying, punching, kicking, driving over protestors with police vehicles and also kidnapping by men in military garb. ${ }^{63}$ The sheer display of overfunding seen through the wide assortments of weapons used on protestors and the blatant brutality towards those protesting 'overfunding and brutality', will only solidify their demands for justice and reforms, the need to shift away from the oppressive system, for now, it was too glaringly clear and transparent that there could be no going back.

\section{Post Covid-19: Road to Reforms}

In a Post-Covid-19 world, America will witness the most socialism-oriented changes. The Black Lives Matter protests have been the largest protests in American history with more than 26 million participants ${ }^{64}$. Since the protests began, a string of left-wing candidates won the elections and were voted to Congress; with more insurgent left-wing candidates predicted to win as the elections progress. Some of the policies they support include police reform, criminal justice reform, Medicare for all, wavering student loans and also keeping the Bernie Sanders' Movement alive. ${ }^{65}$ With Bernie Sanders' loss in the presidential election, several people part of his movement refused to vote for centrist candidate Joe Biden or far-right Donald Trump; deciding to vote for the left-wing Green Party instead. Just 5\% of the votes to the Green party would change the fate of American politics, for it would result in them gaining recognition as a national party, secure federal funding, but most importantly dismantle the reigning system of the biparty neoliberal establishment. ${ }^{66}$ If however, the protests in America become more and more violent, there is a possibility of unrest of a much larger magnitude. Professor Goldstone, a leading authority on the study of revolutions, who was appointed by the White House to study 'how states fail', along with Peter Turchin, developed a model that 'predicts civil wars' by tracking data such as the ratio of median workers' wages to GDP per capita, life expectancy levels, the number of new millionaires, political polarization and the degree of overlap between political parties. When this model was applied to American history, it 'predicted' the 1861 Civil War and the 1930s Jim Crow segregation unrest. Ten years ago, they pointed their model towards the future and observed how the crisis indicators were rising just like in their previous applications. They then deduced that it could be a reliable indicator of a looming instability that

63 Alli Jarrar, 'USA: End unlawful police violence against Black Lives Matter protests', Amnesty International, 23 June 2020, available at https://www.amnesty.org/en/latest/news/2020/06/usa-end-unlawful-policeviolence-against-black-lives-matter-protests/, accessed on 30 July 2020.

${ }_{64}$ Sarah Osei, 'Black Lives Matter Is the Largest Movement in US History', Highsnobiety, 2020, available at https://www.highsnobiety.com/p/black-lives-matter-makes-history/?format=amp, accessed on 30 July 2020 .

65 Reid Wilson, 'Wins by young progressives start reshaping establishment', TheHill, 2020, available at https:// thehill.com/homenews/campaign/502493-wins-by-young-progressives-start-reshaping-establishment, accessed on 30 July 2020.

66 CNBC, 'Why 5\% for the Green Party is a win for America', Consumer News and Business Channel, 27 October 2016, available athttps://www.cnbc.com/2016/10/27/why-5-for-the-green-party-is-a-win-for-americajill-stein-commentary.html, accessed on 30 July 2020. 
was set to peak in the years around "2020", as we are now seeing. In current times they claim that America is 'headed for another civil war' because of reasons that stem from the trends that saw their beginning in the 1980s; 'inequality, selfish elites, and polarization that has crippled the ability of the US government to mount an effective response to the pandemic disease'. ${ }^{67}$ While their model does have an $80 \%$ accuracy rate $^{68}$, the possibility of a civil war is still a prediction, but with the current trajectory of the protests, it cannot be ruled out either.

The rest of the world, whose future isn't hanging on a thread of speculation, will witness an emergence of a socialism oriented international economic order because if capitalism had met the needs of the working class, the class struggle would lose its objective foundation. Socialism would have no connections to the needs and aspirations of the working class and would be reduced to an ethical ideal that expresses a set of moral values, with no privileged class to base it on.

But that isn't the reality we live in and so India will likely be the second country to see more socialism-oriented changes because of the sheer magnitude of unmet needs within the country. The Indian economy was in its worst phase even before Covid-19, the GDP falling to an 11 year low of $4.2 \%$ in $2019-2020^{69}$ and unemployment falling to the lowest it has been in 40 years. To most Indians it has become abundantly clear that Covid-19 was not the only problem, the prevailing system was. With the plight of the migrant workers still fresh in their minds and the toll of the economic downturn; Governments, policy-makers, economists and corporations will have to tread carefully because of how volatile the situation is and how thick the tension is. Unions have already been up in arms in India; over the suspension of over 13 Labor Laws, while bank employees union, IT workers union, students union and automobile unions have also been fighting for aggrieved workers. Because of the Modi Government; 2016, 2019 and the start of 2020 saw two-day nation-wide strikes with each strike being the largest labor action in the world. ${ }^{70}$ With how fragile the system is now and how catastrophic the effects have been, India faces the possibility of strikes of unprecedented magnitudes.

Labor Unions all over the world have been fighting for workers, conducting strikes and staging protests. With the rapidness and magnitude at which strikes are taking place globally, a Post-Covid-19 society will witness a fresh consciousness of power and labor solidarity, economic stoppages as a result of strikes, a unity among broad sections of the working class, an assertion of workers' rights, political influence, workers taking

\footnotetext{
67 James Purtill, 'This model forecast the US's current unrest a decade ago. It now says 'civil war", American Broadcasting Company, 17 June 2020, available at https://www.abc.net.au/triplej/programs/hack/modelpredicting-united-states-disorder-now-points-to-civil-war/12365280, accessed on 31 July 2020.

68 Jack Goldstone, 'A Global Model for Forecasting Political Instability', American Journal of Political Science, volume 54:1, 2010, p. 190.

69 Remya Nair, 'Indian economy grew at 11-year-low of 4.2\% in 2019-20, just 3.1\% in Q4', ThePrint, 29 May 2020, available athttps://theprint.in/economy/indian-economy-grew-at-11-year-low-of-4-2-in-2019-20just-3-1-in-q4/431930/, accessed on 1 August 2020.

70 Subodh Varna, 'Largest Ever Strike in India Shakes Up Modi Govt', Pressenza, 11 January 2020, available at https://www.pressenza.com/2020/01/largest-ever-strike-in-india-shakes-up-modi-govt/, accessed on 1 August 2020.
} 
over organizing society and also the possibility of workers controlling the means of production.

The third country to see more socialism-oriented changes is Brazil. Far-right President Jair Bolsonaro's lackadaisical and apathetic attitude towards the pandemic and the lives lost, has prompted against him 'an extensive campaign of civil disobedience initiated by governors, mayors, the overwhelming majority of religious leaders and the media'. As prominent left-wing politician Ciro Gomes says, not only is he facing a rebellion from regional chiefs but also isolation from his own Cabinet. ${ }^{71}$ Several large-scale protests have broken out against Bolsonaro with multiple left-wing parties participating in them. A commonality shared between the top three countries worst affected by Covid-19 (America, Brazil and India) is that they all have far-right populist leaders who support neoliberalism. One of the possible outcomes for Brazil is a large-scale civil unrest like America, as both Presidents share the exact same ideologies (Bolsonaro even being called 'Tropical Trump'), they both face the same tensions from growing protests and they both govern over crumbling neoliberal states exacerbated by the Covid-19 crisis; $;{ }^{72}$ or the other possible outcome for Brazil is protests of an unprecedented magnitude. But unlike in India, the protests will not be over labor reforms and socialism-oriented changes but over growing left-wing demands for the return of Brazil to the pink tide. With either outcome, Brazil will see the emergence of a socialism oriented economic order.

\section{Conclusion}

While all of this is a speculation based on the analysis of the highest probability and growing trends within these countries, what still remains a surety is the emergence of a socialism oriented international economic order. The resurgence of the pink tide in Latin America that saw its ups and downs since the 1990s will continue to persist in a Post-Covid-19 world with elected left-wing governments in Mexico, Argentina and Venezuela remaining in power backed by a strengthened fervor for socialism while in Bolivia, Ecuador and Chile, socialism-oriented demands and protests will keep continuing. The left-wing political parties that also emerged Pre-Covid-19 in the Republic of Ireland, Quebec and India will play an instrumental role in influencing the politics of their countries ushering a change in the once unquestionable neoliberal capitalist system.

Covid-19 highlighted how a once strong and unquestionable stance in favor of neoliberalism can easily be shattered when 'consciousness' becomes increasingly clear and transparent. It has now been 31 years since Francis Fukuyama wrote his essay 'The End of History?' At that time, he identified as a neoconservative but since then regards

71 Dom Phillips, 'Bolsonaro ignored by state governors amid anger at handling of Covid-19 crisis', The Guardian, April 1 2020, available athttps://www.theguardian.com/world/2020/apr/01/brazil-bolsonaroignored-by-state-governors-amid-anger-at-handling-of-covid-19-crisis, accessed on 1 August 2020.

72 AFP, 'Jair Bolsonaro follows Donald Trump on coronavirus, then goes even further', Deccan Herald, May 27 2020, available athttps://www.deccanherald.com/amp/international/jair-bolsonaro-follows-donaldtrump-on-coronavirus-then-goes-even-further-842276.html, accessed on 1 August 2020. 
financial deregulation as 'elite driven policies that turned out be pretty disastrous' saying, 'there's some reason for ordinary people to be upset'. ${ }^{73}$ Prior to Covid-19, when asked his views about the resurgence of the socialist left in the UK and US, he replied by saying

If you mean redistributive programs that try to redress this big imbalance in both incomes and wealth that has emerged then, yes, I think not only can it (socialism) come back, it ought to come back. This extended period, which started with Reagan and Thatcher, in which a certain set of ideas about the benefits of unregulated markets took hold, in many ways it's had a disastrous effect. ${ }^{74}$

By no means has he now become a socialist but this still remains as an acknowledgement of the flaws of neoliberalism and a nod in favor of social protection. The most notable acknowledgement is however from UK's President, Boris Johnson, who said 'one thing I think the corona virus has already proved is that there is really such a thing as society' choosing to oppose his Conservative predecessor, Margaret Thatcher, who endorsed pure individualism, famously known for saying 'there is no such thing as society'. ${ }^{75}$ In the same interview, Fukuyama also said 'at this juncture, it seems to me that certain things Karl Marx said are turning out to be true ${ }^{76}{ }^{76}$ which is a surprising statement from a man whose essay was built on the premise of rebuking Marxists who regarded communism as humanity's final ideological stage. But as Leon Trotsky asserts, 'just as the operations of the laws of physiology yields different results in a growing than in a dying organism, so the laws of Marxist economy assert themselves differently in a developing and disintegrating capitalism, ${ }^{77}$ whether it be a Welfare State or a ThatcherReagan administration, or even Pre-Covid, Covid or Post Covid societies, the assertion of the laws of Marxist economy prevails and becomes more clear and transparent with increasing consciousness; for Fukuyama, this consciousness was when he realized the motives of financial deregulation, for Boris Johnson, it was when he and his country were battling Covid-19, and for the masses, it was the Covid-19 catalyst.

A Post-Covid-19 society will witness these conscious, aggrieved and unwavering masses forming in the course of resisting capitalism, 'counter-institutions'. What will first begin as organs of a collective struggle, will eventually evolve into alternative institutions of state power. Eric Ruder said

[T] he transition from capitalism to socialism can't be a gradual or

\footnotetext{
73 George Eaton, 'Francis Fukuyama interview: "Socialism ought to come back", New Statesman, 2018, available at https:/ / www.newstatesman.com/culture/observations/2018/10/francis-fukuyama-interviewsocialism-ought-come-back, accessed on 2 August 2020.

74 George Eaton (n 73) (socialism added).

75 PA Media, 'There is such a thing as society, says Boris Johnson from bunker', The Guardian, 29 March 2020, available athttps://www.theguardian.com/politics/2020/mar/29/20000-nhs-staff-return-to-servicejohnson-says-from-coronavirus-isolation, accessed on 2 August 2020.

76 George Eaton (n 73).

77 Internet Archive (n 56).
} 
incremental process by which the state enacts reform and progressively ownership of more and larger chunks of the economy. Rather, socialism represents a radical break with the present system - and depends on the active struggles of workers and their subsequent engagement with every aspect of governing society in their own interest, under the guiding principle of human need before human greed. ${ }^{78}$

This principle of 'human need before human greed' similar to Louis Blanc's statement 'from each according to his abilities, to each according to his needs' ${ }^{79}$ will be the resounding belief moving forward in the transition from capitalism into a PostCovid-19 socialism-oriented international economic order. As Robert Owen once said 'there is but one mode by which man can possess in perpetuity all the happiness which his nature is capable of enjoying,- that is by the union and cooperation of all for the benefit of each'; ${ }^{90}$ and when the Post-Covid-19 society will be rebuilt by depending on the active struggles of workers and their subsequent engagement with every aspect of governing society in their own interests, this perpetuity of happiness will increase a hundredfold.

78 Eric Ruder, 'What is Socialism?', International Socialist Review, available at https://isreview.org/issue/65/ what-socialism-_accessed on 3 August 2020

79 Luc Bovens, 'From Each according to Ability; To Each according to Needs: Origin, Meaning and Development of Socialist Slogans' Forthcoming in History of Political Economy, volume 51:2, 2019, pp. 237257.

80 Sarah Irwing, 'Robert Owen', WordPress, 2009, available at https://www.google.com/amp/s/ radicalmanchester.wordpress.com/2009/09/18/robert-owen/amp/, accessed on 3 August 2020. 